\title{
Electric Power generation crisis in Nigeria: A Review of causes and solutions
}

\section{Ikuobase Emovon $^{1 *}$, Olusegun David Samuel ${ }^{1}$, Chinedum Ogonna Mgbemena ${ }^{1}$, Michael Kanisuru Adeyeri ${ }^{2}$}

\author{
${ }^{1}$ Department of Mechanical Engineering, Federal University of Petroleum Resources, P.M.B. 1221, Effurun, Delta State, \\ NIGERIA. \\ ${ }^{2}$ Department of Mechanical Engineering, Federal University of Technology, P.M.B. 704, Akure, Ondo State, NIGERIA.
}

Received 21 September 2017; accepted 16 November 2017; available online 26 April 2018

\begin{abstract}
The low power generation in Nigeria had hindered her economic growth and industrialisation. The nation had carried out various reform to ameliorate the electric power crisis but all to no avail. The electric power crisis has made so many industries to relocate to more environmental friendly nations. Furthermore, the terrible state of the nation's basic infrastructure such as water supply, health care system and petroleum product distribution are all symptom of an economy that is insalubrious because of the nations' incapability to meet electric power demand. The subject of power generation in Nigeria is interesting, vital and worthy of investigation. Some researchers have investigated the root causes of low power generation in Nigeria and they came up with diverse factors responsible for the lingering electric power crisis. In this research, a review of previous papers in the literature on factors responsible for the low power generation in Nigeria is performed. From the survey, an all-inclusive factors affecting power generation in Nigeria are presented and discussed. On the basis of the number of authors that cited the individual factor, the whole factors are ranked and categorised. Finally, in this paper, general solutions are proffered to minimise /eliminate the major challenges confronting power generation in Nigeria. The research findings revealed that the major challenges confronting power generation in Nigeria are factors such as poor plant maintenance, aged/obsolete equipment and gas pipe line vandalism and that these challenges can be minimised/eliminated through structured maintenance methodology and adequate funding among others.
\end{abstract}

\section{Introduction}

The rate of economic growth and industrialisation of any Nation depends on her ability to produce adequate quantity and quality of electric power and effectively distribute it to power homes and industries. Hence, for Nigeria to achieve her aim of becoming one of the most 20 developed economies in the world, the electric power crisis which has lingered for decades must be completely resolved. The nation has the potentials to resolve the electric power crisis because she is endowed with vast varieties of both renewable and non-renewable energy resources [1]. For example, the country is blessed with an estimated reserve of 185 trillion cubic feet, 2.75 billion tons and 35 billion barrels of natural gas, coal and crude oil, respectively [1,2]. The above quantity of non- renewable energy reserve is adequate to meet the electric power demand of sub-Saharan Africa for several decades [2]. In addition to the non-renewable sources, the nation is endowed with several renewable sources of energy such as wind, solar and biomass. The sources and estimated reserves for different varieties of both renewable and nonrenewable energy are presented in Table 1.

Despite the abundance sources of energy available for power generation, the nation remains one of the lowest electric power consumption per capita in Africa [4,5]. For example, the electric power consumption per capita is barely $144 \mathrm{KWH}$ which is very low compared to that of South Africa, Egypt, Libya, Namibia and Botswana with electricity consumption per capita of 4,229, 1,699, 1841, 1,564 , respectively. The electric power consumption per capital in most Africa countries are presented in Figure 1.

The bodies entrusted with electric power generation by the Federal Government of Nigeria for decades' had the capacity of generating less than $5000 \mathrm{MW}$ of electric power which translated to the electric power consumption per capita of $144 \mathrm{KWH}$. However, Nigeria requires not less than 140, $000 \mathrm{MW}$ to meet her energy demand [7]. This

*Corresponding author: emovon.ikuobase@fupre.edu.ng 
scenario resulted to most Nigerians producing electric power using stand-by generators to power their homes and businesses whenever there is power outage from the national grid. Braimoh and Okedeji, [8] highlighted that Nigeria is the largest users of stand-by power generators in the world. The survey conducted by NOI Polls Ltd in 2013 revealed that about 130 million Nigerians out of a population of 160 million rely solely on the stand-by generating set to satisfy their electric power demand [9]. However, the use of the generating set by individuals had resulted to serious environmental degradation and high cost of running business. This situation has forced many industries to relocate to more environmental friendly countries and others became moribund.

Table 1: Energy source and reserve estimates [3]

\begin{tabular}{lll}
\hline S/N & Energy Type & Reserves estimates \\
\hline 1 & Crude oil & 36 billion barrels \\
2 & Natural gas & 185 trillion cubic feet \\
3 & coal & 2.75 billion metric tons \\
4 & Hydro & $14,750 \mathrm{MW}$ \\
5 & Solar radiation & $3.5-7.0 \mathrm{Kwh} / \mathrm{m}^{2}$-day \\
6 & Wind energy & $2.0-4.0 \mathrm{~m} / \mathrm{s}$ \\
7 & Biomass & $144 \mathrm{million}$ tons $/$ year \\
& Wave and tidal & $150,000 \mathrm{TK} /(16.6 \mathrm{x} 106$ \\
8 & energy & toe/year $)$ \\
\hline
\end{tabular}

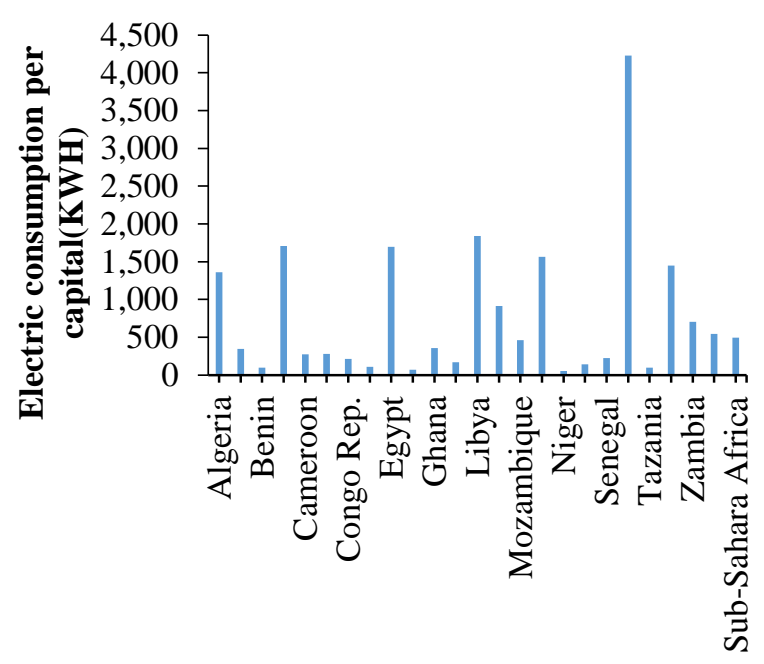

Countries

Fig. 1 Electricity consumption per capita in most African countries $[5,6]$

To address the electric power deficit, successive government had carried out various reforms. For example, between 1999 and 2004 there was substantial asset overhaul and between 2004 and 2014 there was massive asset expansion by the Federal Government of Nigeria [10]. However, in spite of these reforms, electric power crisis remains unresolved with no end in sight.

From the above analysis, it is obvious that the subject of power generation in Nigeria is interesting and important and worthy of investigation. In the literature, different authors had presented papers on factors responsible for the abysmal low electric power production in Nigeria. Ohajianya et al., [11] articulated factors responsible for epileptic power supply in Nigeria to include among others; inappropriate power reforms and inept workforce. Sambo et al., [12] remarked that factors such as lack of fund and low private sector participation as the bane of electric power crisis in Nigeria. Furthermore, Emovon and Samuel [5] opined that lack of energy mix and policy continuity among others are the causes of low power generation in Nigeria.

The main purpose of this paper is to review previous literature and identify and discussed an all-inclusive factors affecting power generation in Nigeria. Furthermore, the whole factors will be ranked and categorised based on the number of authors that identified with the individual factors. Finally, general solutions will be proffered to problems be-devilling power generation in Nigeria.

\section{History of Power Generation in Nigeria}

The first electric power plant was developed in Lagos, Nigeria in 1986 and later other individual power plant units were installed at Ibadan, Kano and Warri [13]. The individual units were operated either by native authority or by the public works department [13]. The Electricity Corporation of Nigeria (ECN) was established by an act of parliament in 1951 to manage all the individual power plant units [14]. The need to develop hydro-electric power led to the establishment of Niger Dam Authority (NDA) in 1962. In 1972, the ECN and NDA were merged to form the National Electric Power Authority (NEPA) $[15,16]$ and the body owned by the Federal Government of Nigeria managed the generation, transmission and distribution/marketing components of the power system until January 2004 when it was unbundled into six generating companies, 1 transmission and 11 distributions [17].

The eighteen Companies were incorporated as Power Holding Corporation of Nigeria (PHCN) [17]. In March 2005, the Nigeria power Sector Reform bill was sign into law in order to allow for private sector participation in the generation, transmission and distribution of electricity [12, 18]. This resulted in the emergence of Independent Power Producers (IPP) with foreign, local and state government participation in the generation of electricity and they were mandated to sell electric power produced to PHCN. For effective operation of the activities in the power sector, Nigerian Electricity Regulatory Commission (NERC) was set up in November 2005 to monitor service quality and 
electricity tariff of the PHCN. By 2012, the IPP contributed $25 \%$ of the total electric power produced in Nigeria with the remaining contributed by PHCN [19]. PHCN was eventually privatised on November 5, 2013 and all its assets and liabilities handed over to different private Companies [11]. With the sector fully deregulated the generation, transmission and distribution activities of the power sector is now private sector driven. However, the quality of service and tariff is being regulated by the Federal Government of Nigeria through NERC.

\section{Methodology}

The methodological steps of this paper on power generation in Nigeria are presented in Figure 2 and is described as follows:

(a) Literature survey on factors affecting power generation in Nigeria

(1)

(b) All-inclusive factors that affect power generation from the survey \& description

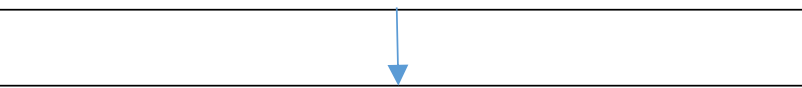

(c) Identification of the number of authors that cited each factor

(d) Ranking and categorisation of factors based on number of authors that cited them

(e) Generalised solutions for addressing power generation challenges

Fig. 2 Flow diagram of the paper methodological steps
Step a: A thorough literature survey on factors affecting power generation in Nigeria is carried out. The various factors suggested by different authors are presented in Tabular form.

Step b: An all-inclusive list of factors obtained from the survey are prepared and described in Tabular form.

Step c: A table is also prepared which contain list of factors together with the number of authors that cited each factor.

Step d: here the whole factors are ranked and categorise based on the number of authors that cited them.

Step e: A generalised solutions for overcoming the challenges confronting power generation are discussed.

\section{Literature survey on factors affecting power generation in Nigeria}

The epileptic power supply to homes and industries in Nigeria as previously stated is the major barrier to her economic growth. The backbone of the power system is the power generation component because it is the quantity of power generated that can be transmitted and distributed to homes and industries. This component of the power system had suffered ingloriously from poor funding, poor or lack of maintenance and poor management of infrastructure among other factors which had resulted in to many of the power generation station packing up and others generating power far below their installed capacity. From the literature, different authors had opined various reasons for the low power generation; although power demand in Nigeria is geometrically increasing. The reasons/factors cited by the various authors are presented in Table 2.

\section{All-inclusive factors that affect power generation from the survey $\&$ description}

From the literature review in Table 2, 23 factors were observed to be responsible for the low power generation in Nigeria, and the factors are described in Table 3. 
Table 2: Literature survey on factors affecting power generation

\begin{tabular}{lll}
\hline Author names & Types & Factors identified \\
\hline Emovon \& Samuel [5] & Journal & (1) Poor plant maintenance (2) Inadequate funding (3) inadequate \\
& manpower (4) militant activities (5) wrong location (6) seasonal \\
drought (7) poor electricity pricing (8) Lack of policy continuity (9) \\
corruption
\end{tabular}

Ohajianya et al [11] Journal (1) Inconsistent energy policy (2) inept workforce

Idigbe \& Igbinosa [20] Journal (1) lack of energy mix (2) Poor electricity pricing (3) obsolete facilities (4) poor policy on natural gas (5) poor funding (6) social factor

Sule, [13] Journal

(1) Pipe line vandalism (2) kidnapping of local \& foreign experts (3)gas flaring (4) seasonal drought (5) poor plant maintenance (6) bribery \& corruption (7) lack of energy mix (8) customers indebtedness to power providers (9) absence of Research \& development

Onohaebi \& Lawal [21] Journal

(1) Poor plant maintenance (2) Inadequate funding (3) Unskilled manpower (4) Inadequate staff training (5) Over-aged \& obsolete equipment

Obadote [16] Journal

(1)Poor plant maintenance (2) inadequate gas pipeline maintenance (3) inadequate gas supply (4) Low gas pressure (5) Pipeline vandalism by Militant (6) seasonal drought (7) climate change

Iwayemi [1]

Conference paper

(1)Militant activities (2) Aged equipment (3) poor maintenance (4) Customers indebtedness to power providers (5) Corruption (6) High cost operation

Adenikinju $[22,23] \quad$ Journal

Sambo et al, [21] Technical report

(1) Obsolete \& dilapidated plants (2) poor asset management

(1) Poor plant maintenance (2) inadequate funding (3) obsolete equipment (4) Lack of energy mix (5) Low staff moral \& inadequate training (6) unwholesome practice by staff (7) poor electricity billing

Table 3: Description of the-factors affecting power generation

\begin{tabular}{lll}
\hline S/N & $\begin{array}{l}\text { Factors } \\
\text { identified }\end{array}$ & Descriptions \\
\hline 1 & $\begin{array}{l}\text { Poor plant } \\
\text { maintenance }\end{array}$ & $\begin{array}{l}\text { Maintenance are generally of two types, preventive and corrective maintenance. The preventive } \\
\text { maintenance is either time based or condition based. The type of maintenance suitable for } \\
\text { different power plant equipment depend on the equipment criticality to the entire plant. Hence } \\
\text { for optimal performance of plant at minimum cost a suitable technique must be adopted for each } \\
\text { plant equipment. However the maintenance approach use by most power plant station in Nigeria } \\
\text { is corrective maintenance and in some cases equipment maintenance are not even performed. } \\
\end{array}$ \\
& $\begin{array}{l}\text { The end effect is low power generation output. } \\
\text { Inadequate } \\
\text { funding }\end{array}$ & $\begin{array}{l}\text { Fund for power equipment infrastructure maintenance, upgrade and expansion is inadequate } \\
\text { which had been worsen with the dwindling global price of crude oil. }\end{array}$ \\
& $\begin{array}{l}\text { Pipeline pipe line that carries natural gas to the thermal power stations are frequently being } \\
\text { vandalism }\end{array}$ & $\begin{array}{l}\text { The pandalized by militants in response to government failure to give them employment and provide } \\
\text { basic amenities for their communities. This result to frequent disruption of gas supply to thermal } \\
\text { power stations and frequent shutdown of power generating plants. }\end{array}$
\end{tabular}


Poor asset management

15 Customers indebtedness to power providers

16 High cost of operation

wrong location

Unskilled manpower mix

Inadequate staff training

Aged or Obsolete equipment

Low staff morale drought

Poor electricity pricing

Lack of policy continuity

Inadequate gas supply

\section{Climate change}

Inadequate gas pipeline maintenance

Unwholesome practice by staff
Power stations in some cases are sited far away from energy sources due to nepotism and ethnicity. The effect are usually multifaceted ranging from extra cost in transporting materials and human resources to power plant sites to possibilities of vandalism of materials in transit [5]

Inadequate skilled manpower with the expertise to maintain, upgrade and expand power generation systems.

Nigeria had relied mainly on oil, gas and hydro as energy source for power generation and has fail to explore other sources of energy such as solar, wave and tidal energy and biomass. These alternative sources can supplement existing sources for greater power output.

Mainly due to insufficient fund or misplace priority, staffs are not expose to state of art technology through local and oversea training for optimal day to day running of power generation systems.

Most of the power infrastructure have been built for several decades. For example 36\% of the plants are over 20 years, $48 \%$ are over 15 years old and $80 \%$ are over $10 \%$ years [23]. Hence majority of the plant are in the wear and tear region and as such often breakdown.

Staff morale is generally low due to poor remuneration

During draught period which occurs in the dry season and from the month of march to June, the water level is very low which affect negatively hydro power generation [24].

Since the failed privatisation of the power sector, most of the private investors engaged in unwholesome practice of giving out outrageous bills to electricity consumers in the name of estimated bills. The estimated billing system had been counter-productive as consumers cannot pay the outrageous bills due to their meagre income and they had resorted to bribing power distribution companies' staff to continue to enjoy electric power supply. The bills should be affordable to encourage consumers to pay, so that there will be sufficient fund to maintain, upgrade and expand power generation infrastructure.

Instead of building on good policies of previous administration, the policies are jettisoned and new policies activated will be eventually be discarded by another Government [5].

Due to frequent shutdown of gas plant and vandalism of gas pipeline by the militant group and other agitators coupled with daily flaring of gas by multinational oil companies', most thermal stations from time do not get adequate gas supply to generate electricity.

Privatization carried out by the Nigeria government was a charade. The assets were sold to themselves and their political associate. These investors do not have the technical and managerial skills to optimally manage power generation infrastructure for maximum power productivity.

Electricity consumers in some cases are not patriotic with respect to their responsibility of paying for electricity consumed [13]. Individuals, local government, State and Federal government agencies are owning power companies billions of Naira. The debt if paid would go a long way in ameliorating power crisis in Nigeria.

High cost of operation due to the following reasons (1) high cost of purchase of spare parts to carry out maintenance (2) High cost of hiring foreign expatriates as result of limited number of local experts.

The effect of global warming which brought about climate change has negatively affect water level at hydro power generation stations and invariably resulting to reduction in power generation output [24].

The pipe line that transport natural gas to power thermal station are not maintain as at when due and this do result to frequent pipeline failure [16]

Some technical staff sabotage the system by deliberately allowing equipment to fail from time to time so that they can request for fund and bulk of the fund are diverted into personal use. Others procure substandard equipment to fix plant system thereby making the system to fail 
catastrophically.

20 Absence of research \& development

22 Kidnapping of local \& foreign experts

23 Corruption

There is absence of research and development especially as it concern best approach to adapt alternative sources of energy such nuclear, solar and biomass to supplement existing energy sources for greater electric power production output [13]

Both local and foreign experts are subjected to inhuman treatment by kidnappers who kidnap for ransom. These had resulted to some foreign experts resigning and relocating back to their countries and invariably shortage of skilled manpower to optimally operate, maintain and expand power generation infrastructure in Nigeria.

From the lower staff cadre to the management level corruption thrive. Meagre resource available for power infrastructure maintenance, upgrade and expansion is either embezzled or mismanage by power generation managers [5]

\section{Identification of the number of authors that cited each factor}

Having described the factors affecting power generation in Nigeria, the next step in this paper methodology is to determine the number of authors that cited each factor and the results are presented in Table 4. As can be noticed in Table 4, factors such as poor plant maintenance were indicated to be highly responsible, followed by aged/obsolete equipment, then inadequate funding and pipe vandalizing. This was followed by corruption, seasonal drought, poor electricity supply, customers' indebtedness while factors such as kidnapping of local and foreign experts, absence of research and development, unwholesome practice by staff, High cost of operation, Inadequate gas supply, poor asset management, low staff morale, etc. were rarely cited.

\section{Ranking and categorisation of factors based on the number of authors}

As can be observed from Table 4, individual factors are mostly cited by a maximum of 1 and 6 authors. To rank and categorise these factors, a 3 point likert scale is applied. The 3 point likert scale is indicated in Table 5.

Table 5: 3 point Likert scale developed for categorisation of factors affecting power generation

\begin{tabular}{cc|} 
Numbers of authors & Criticality \\
\hline $5-6$ & Most critical \\
$3-4$ & Critical \\
$1-2$ & Less critical \\
\hline
\end{tabular}

Applying the Likert scale in Table 5 to information in Table 4, the factors affecting generation are categorise into three groups; group 1, most critical factors, group 2 critical factors and group 3 less critical factors and results are presented in Table 6.

Table 6, shows three groups of factors. Group 1 consisting of factors such as poor plant equipment and aged or obsolete equipment having been cited by 5 or 6 authors are denoted most critical factors affecting electric power generation. Group 2 consist of factors such as lack of energy mix and gas pipe line vandalism having been cited by 3 or 4 authors are denoted as critical factors affecting power generation. Group 3 consisting of factors such as absence of research and development and climate change are denoted less critical factors affecting power generation having been cited by either 1 or 2 author.

Table 4: Power generation problems

\begin{tabular}{|c|c|c|c|}
\hline $\mathbf{S} / \mathbf{N}$ & $\begin{array}{l}\text { Factors } \\
\text { identified }\end{array}$ & Authors & $\begin{array}{c}\begin{array}{c}\text { Number } \\
\text { of authors }\end{array} \\
\end{array}$ \\
\hline 1 & $\begin{array}{l}\text { Poor plant } \\
\text { maintenance }\end{array}$ & $\begin{array}{c}{[5],[13],[21],[1} \\
6],[12],[1]\end{array}$ & 6 \\
\hline 2 & $\begin{array}{l}\text { Inadequate } \\
\text { funding }\end{array}$ & $\begin{array}{c}{[5],[20],[21]} \\
{[12]}\end{array}$ & 4 \\
\hline 3 & $\begin{array}{l}\text { Pipeline } \\
\text { vandalism }\end{array}$ & $\begin{array}{c}{[5],[13],[16],} \\
{[1]}\end{array}$ & 4 \\
\hline 4 & Wrong location & [5] & 1 \\
\hline 5 & $\begin{array}{l}\text { Unskilled } \\
\text { manpower }\end{array}$ & {$[21],[11]$} & 2 \\
\hline 6 & $\begin{array}{l}\text { Lack of energy } \\
\operatorname{mix}\end{array}$ & {$[20],[13],[12]$} & 3 \\
\hline 7 & $\begin{array}{l}\text { Inadequate staff } \\
\text { training }\end{array}$ & {$[21],[12]$} & 2 \\
\hline 8 & $\begin{array}{l}\text { Aged or } \\
\text { Obsolete } \\
\text { equipment }\end{array}$ & $\begin{array}{c}\text { [20], [21], } \\
{[12],[22],[1]}\end{array}$ & 5 \\
\hline 9 & Low staff moral & [12] & 1 \\
\hline 10 & Seasonal drought & [5], [13], [16] & 3 \\
\hline 11 & $\begin{array}{l}\text { Poor electricity } \\
\text { pricing }\end{array}$ & [5], [20], [12] & 3 \\
\hline 12 & $\begin{array}{l}\text { Lack of policy } \\
\text { continuity }\end{array}$ & [5], [11] & 2 \\
\hline 13 & $\begin{array}{l}\text { Inadequate gas } \\
\text { supply }\end{array}$ & [16] & 1 \\
\hline 14 & $\begin{array}{l}\text { Poor asset } \\
\text { management }\end{array}$ & {$[22,23]$} & 1 \\
\hline 15 & $\begin{array}{l}\text { Customers } \\
\text { indebtedness to } \\
\text { power providers }\end{array}$ & [13], [1] & 2 \\
\hline
\end{tabular}




\begin{tabular}{llcc}
16 & $\begin{array}{l}\text { High cost of } \\
\text { operation } \\
\text { Climate change }\end{array}$ & {$[16]$} & 1 \\
18 & $\begin{array}{l}\text { Inadequate } \\
\text { pipeline } \\
\text { maintenance } \\
\text { Poor policy on } \\
\text { natural gas }\end{array}$ & {$[16]$} & 1 \\
19 & $\begin{array}{l}\text { Unwholesome } \\
\text { practice by staff }\end{array}$ & {$[12]$} & 1 \\
21 & $\begin{array}{l}\text { Absence of } \\
\text { research \& } \\
\text { development } \\
\text { Kidnapping of } \\
\text { local \& foreign } \\
\text { experts } \\
\text { Corruption }\end{array}$ & {$[12]$} & 1 \\
23 & {$[13],[13],[1]$} & 3 \\
\hline
\end{tabular}

Table 6: Rank and classification of electric power problems.

\begin{tabular}{|c|c|c|c|c|}
\hline$\frac{\pi}{Z}$ & 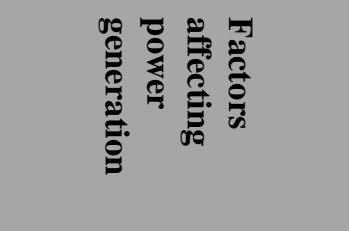 & 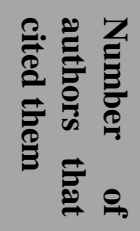 & 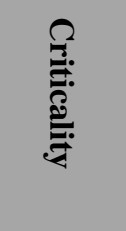 & 气̊ \\
\hline 1 & Poor plant maintenance & & & \\
\hline 2 & $\begin{array}{l}\text { Aged or Obsolete } \\
\text { equipment }\end{array}$ & $5-6$ & $\begin{array}{l}\text { Most } \\
\text { critical }\end{array}$ & 1 \\
\hline 1 & Pipeline vandalism & & & \\
\hline 2 & Lack of energy mix & & & \\
\hline 3 & Inadequate funding & & Critica & 2 \\
\hline 4 & Seasonal drought & 3-4 & 1 & 2 \\
\hline 5 & Poor electricity pricing & & & \\
\hline 6 & Corruption & & & \\
\hline 1 & Unskilled manpower & & & \\
\hline 2 & $\begin{array}{l}\text { Lack of policy } \\
\text { continuity }\end{array}$ & & & \\
\hline 3 & $\begin{array}{l}\text { Customers } \\
\text { indebtedness to power } \\
\text { providers }\end{array}$ & & & \\
\hline 4 & $\begin{array}{l}\text { Inadequate staff } \\
\text { training }\end{array}$ & & & \\
\hline 5 & wrong location & $1-2$ & Less & 3 \\
\hline 6 & Low staff moral & $1-2$ & critical & 3 \\
\hline 7 & Inadequate gas supply & & & \\
\hline 8 & Poor asset management & & & \\
\hline 9 & High cost of operation & & & \\
\hline 10 & Climate change & & & \\
\hline 11 & $\begin{array}{l}\text { Inadequate pipeline } \\
\text { maintenance }\end{array}$ & & & \\
\hline 12 & $\begin{array}{l}\text { Poor policy on natural } \\
\text { gas }\end{array}$ & & & \\
\hline
\end{tabular}

\begin{tabular}{ll}
\hline 13 & $\begin{array}{l}\text { Unwholesome practice } \\
\text { by staff } \\
\text { Absence of research \& } \\
\text { development }\end{array}$ \\
15 & $\begin{array}{l}\text { Kidnapping of local \& } \\
\text { foreign experts }\end{array}$ \\
\hline
\end{tabular}

From Table 6, it is obvious that factors in group 1 are the main causes of poor power generation in Nigeria while factors in group 3 possess the least threat to power generation in Nigeria. It is advisable that greater attention be paid to factors in group 1 and 2 by power generation managers if the electric power crisis in Nigeria must be resolved. General solutions to the major challenges bedevilling power generation in Nigeria are presented next.

\section{Solutions to Power Generation Problems in Nigeria}

Since the engine that drives industrialization is electric power a stable electric power supply is the key for Nigeria to becomes one of the most 20 developed economy in the world. To achieve stable electric power supply to power industries and homes the country must be able to generate enough electric power to meet her demand. However, in order to meet up with the power demand, the various challenges discussed in Table 3 that had bedevilled the sector must be overcome. From literature, interviews with power experts and based on our own opinion, the general solutions to the challenges bedevilling power generation in Nigeria are described as follows:

\subsection{Energy mix}

No nation in the world can satisfy it electric power demand by generating it from one or two sources. To meet up with the high demand of electric power and to achieve any set goal there is a need to utilise multiple sources of energy with a well-articulated electric power policy frame work. The low power generation experienced in Nigeria since independence is mainly due to the fact that the nation concentrated all her efforts in generating electric power from only two sources namely hydro and natural gas. Unfortunately the two energy sources have been poorly harnessed and managed [25].

For the country to overcome the challenge of low power generation, there is a need to supplement both hydro and gas with other energy source such as solar, biomass and wind and based on Nigeria technological level of development coal should contribute at least 20 percent of energy needed for electricity generation; nuclear 10 percent, wind 10 percent solar 20 percent and the other sources such as biofuel should contribute the reminder [25]. Also, proper management of this energy mix can guarantee stable electric power supply in Nigeria. 


\subsection{Structured maintenance methodology}

Maintenance can be defined as all activities carried out on plant system to preserve the system in, or restore it to a state in which it can perform its design functions [26]. These activities may include repairs and replacement of plant system equipment or component and are carried out either on the basis of the condition of the plant system or at specific time interval [27]. Basically there are three types of maintenance namely; reactive, time based and condition based maintenance. However, the type to be applied to a particular plant system equipment or component depends on the criticality of the equipment or component to the entire system. Hence to achieve optimal plant system performance at reasonable cost, a combination of different maintenance type or strategy must be applied to the entire plant system through a well design structured maintenance methodology.

However in Nigeria, maintenance is still regarded as an unwanted cost generating activity rather than one that will produce greater plant system safety, availability and reliability and invariably higher Company profitability and productivity [28]. The misconception about maintenance by government and power managers is the dominant reason we were projecting target of 6000MW by December 2009 when the nation actually attained not less than 6000MW installed power capacity since 1985 . Until there is a complete change of attitude towards maintenance by government and power generation managers, the power crisis will be a crisis without an end.

For the nation to achieve her aim of generating adequate electric power to meet power demand, there is need for a structured maintenance methodology for the maintenance of her power infrastructure which must entail the following: right attitude toward maintenance, adequate budgetary provision for maintenance, plant system equipment or component risk analysis system, maintenance strategy selection methodology, spare parts inventory programme and an instrument such as computerized maintenance management systems (CMMS) for data collection and analysis.

\subsection{Adequate funding}

For Nigeria to achieve her aim of becoming one of the most industrialised nation in the world, the current electricpower generation capacity of less than $6000 \mathrm{MW}$ will have to rise to $160 \mathrm{GW}$ by $2030 \mathrm{AD}$ [3]. The authors further stated that this level of electric power supply will increase the electricity consumption per capital from the current level of $144 \mathrm{KWH}$ to about $5000 \mathrm{KWH}$ by the year 2030 . The $5000 \mathrm{KWH}$ is only comparable to the electricity consumption per capital achieved by some industrialised nations in the year 2003. The total financial resource to attain this target is an estimate of about US\$262billion or a yearly investment of about US\$ 10billion [3]. However, the dwindling oil revenue due to global economic melt-down, coupled with high level of corruption and mismanagement have increased the competition for public funds and has reduced government capacity to adequately meet the financial obligation of the power sector. Even when resources are made available the money will end up in the pocket of few individuals and the end product is that the project will be abandoned or will not even be executed.

However if the problem of electricity crisis must be resolved, adequate finance must be set aside for the operation, maintenance, upgrading and expansion of the power sector infrastructure. Nevertheless, due to the enormous financial resources involved Federal, a state, local government of Nigeria must support the private investor financially by way of grant and waivers. Additionally, the citizens of the country must be patriotic and regularly pay for electric power consumed so that private investors will have adequate resources to achieve the goal of matching supply with demand.

\subsection{Elimination or minimisation of corruption}

If the nation wants to achieve her aim of a generating adequate electricity to power homes and industries, corruption in the power sector must be eliminated. To achieve zero corruption in the sector, the government must ensure revenue generated from sales of electricity by the power managers to consumers must be reinvested into the sector, for maintenance, upgrading and infrastructure expansion in order for the resources not to end up in individuals' pocket. The government must also ensure that any power manager found wanting be investigated by the Economic Financial Crime Commission (EFCC) and be prosecuted. Furthermore, the fraudulent practice of estimated billing of consumers by electric power distributors/marketers must be strongly condemned and Government must ensure electricity meters are provided to power consumers. This will reduce corruption perpetrated by staff of power distributing companies and electric power consumers. These suggestions if carried out by government will reduce financial resource leakage and there will be sufficient fund to maintain, upgrade and expand power infrastructure for maximum power productivity.

\subsection{Elimination or reduction of gas pipe line and other related infrastructure vandalism.}

Gas pipeline and other related infrastructure vandalism are activities carried out by the Niger Delta militants and other Agitators and to reduce or eliminate this activities, the Agitators must be encouraged to drop arms against the state. To achieve this aim, they must be integrated back into the society through provision of formal education and subsequently gainful employment [10]. In addition, this issue of providing basic amenities to the Niger Delta people and making the environment more habitable must be government priority. This to a large extent will eliminate 
gas supply interruption to gas thermal power station and invariably improved power generation output.

\section{Conclusions}

In spite of the abundance energy sources such as solar, wind and tidal energy and biomass in Nigeria, the nation remains one of the lowest electricity consumption per capita in Africa. The reasons for the low power generation capacity had been discussed in the literature by different authors in diverse ways. In this paper, a thorough literature survey was conducted with respect to providing a comprehensive list of factors affecting power generation in Nigeria. The all-inclusive factors were discussed and categorised based on the number of authors that cited them. The factors were categorised into three groups; group 1, most critical factors, group 2, critical and group 3, less critical factors. From the research analysis, poor plant maintenance and aged/obsolete equipment which belong to group 1 are the main causes of low power generation in Nigeria. In order to address these challenges, a generalised solutions which include energy mix, adequate funding, structured maintenance methodology and elimination of corruption were suggested. The research will go a long way in assisting power generation Managers in ameliorating electric power crisis in Nigeria and in other countries with similar challenges. For future work, MultiCriteria Decision Making (MCDM) tools such as Complex Proportional Assessment (COPRAS) and Additive Ratio Assessment (ARAS) can be explored in the categorisation of the factors affecting power generations.

\section{Acknowledgements}

The authors would like to thank the Federal University of Petroleum resources, Effurun, Nigeria for providing the enabling environment for conducting this research.

\section{References}

[1] Iwayemi, A. Investment in electricity generation and transmission in Nigeria: issues and option, International Association for Energy Economics, First Quarter, (2008), pp. 37-42.

[2] Ayogu, M. Infrastructure Development in Africa: Prospects and Challenges. Proceedings of African Development Bank on Economic Development in the Millennium. AERC-AfDB Project on Africa's development, Tunis, (2006).

[3] Ibitoye, F.I. and Adenikinju, A. Future electricity demand in Nigeria, Applied energy, Volume 84, Number 5, (2007), pp. 492- 504.

[4] Olaoye, T. Ajilore, T., Akinluwade, K., Omole, F., and Adetunji, A. Energy Crisis in Nigeria: Need for Renewable Energy mix. American Journal of Electrical Electronics Engineering, Volume 4, Number 1, (2016), pp. 1-8.
[5] Emovon, I. and Samuel, O.D. An integrated Statistical Variance and VIKOR methods for Prioritising Power Generation problems in Nigeria. Journal of Engineering and Technology, Volume 8, Number 1, (2017a), pp. 92-104.

[6] World Bank, Electric power consumption (KWH per capita), <http://www.data.worldbank org/indicator/EG.USE.ELEC.KH.PC>, 2015 (Retrieved 15:08:17)

[7] Uzorh, A.C. and Innocent, N. Solution to Power Generation shortage using Solar Energy. The international Journal of Engineering and Science, Volume 3, Number 6, (2014), pp. 23-27.

[8] Braimoh and Okedeyi, Energy and Power Generation, Transmission and Distribution in Lagos State, $<$ http://cefolassaocoed.net/index.php?option = com_content\&view=article \&id=83\& Itemid=88\&limitstart=4>2010 $($ Retrieved 26: 09: 17)

[9] IseOlorunkanmi, O.J. Issues and challenges in the privatised power sector in Nigeria. Journal of sustainable development studies, Volume 6, Number 1, (2014), pp. 161-174.

[10] Emovon, I. and Samuel, O. D. Prioritising Alternative Solutions to Power Generation problems using MCDM Techniques: Nigeria as Case Study. International Journal of Integrated Engineering, Volume 9 Number 3, (2017b), pp. 11-17.

[11] Ohajianya, A.C., Abumere, O.E., Owate, I.O. and Osarolube, E. Erratic Power Supply in Nigeria: Causes and Solutions. International Journal of Engineering Science Invention, Volume 3, Number 7, (2014), pp. 51-55.

[12] Sambo, A.S., Garba, B., Zarma, I.H. and Gaji, M.M. Electricity Generation and the Present Challenges in the Nigerian, Power Sector, Energy Commission of Nigeria, Abuja-Nigeria.

[13]Sule, A.H. Major factors affecting electricity generation, transmission and distribution in Nigeria. International Journal of Engineering and Mathematics Intelligence, Volume 1, (2010), pp. 159-164

[14] Uwaifo, S.O. Electric Power distribution Planning and development, 1st Ed., Malt-house Press Ltd, Marina, Nigeria.1994

[15]Niger Power Review. Development of Electricity industry in Nigeria (1960-1989), pp. 10-15.

[16] Obadote, D.J. Energy crisis in Nigeria: technical issues and solutions. Power sector prayer conference, (2009), pp. 1-9.

[17] Ajumogobia and Okeke, Nigerian Energy Sector: Legal and Regulatory overview (2015)

[18]Eleje, E.O. Anienwelu, P.C. and Bosun-Fakunle, Y.F. Government policy on privatization of power in Nigeria: end-users financial cost perspective. Journal of Research in national Development, Volume 15, Number 1, (2017), pp. 351-356. 
[19] Oladipo, F. and Temitayo, O. The Nigerian Power System till Date: A Review. International Journal of Advance Foundation and Research in Science and Engineering, Volume 1, Number 5, (2014), pp. 20-33.

[20] Idigbe, K.I. and Igbinovia, S.O. Assessing the sustainability of electric power in Nigeria: a case study of the IPPs. Journal of Economics and Engineering, (2010), pp. 70-77.

[21] Onohaebi, O.S. and Lawal, Y.O. Poor maintenance culture; the bane to electric power generation in Nigeria. Journal of Economics and Engineering, (2010), pp. 28-33.

[22] Adenikinju, A.F. Electric infrastructure failures in Nigeria: a survey-based analysis of the costs and adjustment responses. Energy policy, Volume 31, Number 14, (2003), pp. 1519-1530.

[23] Adenikinju, A.F. Analysis of the cost of infrastructure failures in a developing economy: The case of the electricity sector in Nigeria. African Economic Research Consortium lecture series, AERC Research paper 148, (2005), pp. 1-44.

[24] Sada, I. Analysis on Generation Transmission and Distribution of Nigeria Power for National development. Proceedings of the 2nd National Conference of Colleges of Agriculture, Environmental, Engineering and Science and Technology, Hassan Usman Katsina, Polytechnic, Katsina state Nigeria, (2007).

[25] Onyekakeyah, L. Energy mix as key to guaranteed power supply, The Punch, $17^{\text {th }}$ November, (2009), pp. 79.

[26] Dhillon, B.S. Engineering maintenance: A modern approach. Florida: CRC press, (2002).

[27]Emovon, I., Norman, R.A. and Murphy, A.J. An integration of multi-criteria decision making techniques with a delay time model for determination of inspection intervals for marine machinery systems. Applied Ocean Research, Volume 59, (2016), pp. 65-82.

[28] Eti, M.C., Ogaji, S.O.T. and Probert, S.D., 2004. Reliability of the Afam electric power generating station, Nigeria. Applied Energy, Volume 77, Number 3, pp.309-315. 